\title{
PENGGUNAAN METODE JARIMATIKA DAN DRILL UNTUK MENINGKATKAN HASIL BELAJAR MATERI OPERASI PERKALIAN PADA SISWA KELAS III MI NU MIFTAHUT THOLIBIN MEJOBO KUDUS
}

\author{
Elya Umi Hanik ${ }^{1)}$, Muhammad Rizky Pratama ${ }^{2)}$, Uswatun Khasanah ${ }^{3{ }^{*}}$, Hapsari Cahyaning Putri ${ }^{4)}$ \\ 1),2), 3,) 4) Pendidikan Guru Madrasah Ibtidaiyah, Fakultas Tarbiyah - IAIN Kudus \\ *Corresponding Author: uswatunkh052@gmail.com
}

\begin{tabular}{|c|c|}
\hline ARTICLE INFO & ABSTRACT \\
\hline $\begin{array}{l}\text { Article history } \\
\text { Received: October } 15^{\text {st }}, 2021 \\
\text { Revised: November } 29^{\text {st }}, 2021 \\
\text { Accepted: December } 8^{\text {st }}, 2021 \\
\text { Keywords: } \\
\text { Jarimatika Method, Drill Method, } \\
\text { Multiplication Operation, } \\
\text { learning outcomes. }\end{array}$ & $\begin{array}{l}\text { This study aims to improve the learning outcomes of students' } \\
\text { mathematical multiplication operations using the drill method and the } \\
\text { Jarimatika method. This classroom action research was carried out } \\
\text { in } 2 \text { cycles with four stages, namely: planning, implementation, } \\
\text { observation, reflection. The subjects of this study were the class III } \\
\text { students of MI Miftahut Tholibin Mejobo Kudus as many as } 17 \\
\text { students. This study uses qualitative descriptive analysis techniques } \\
\text { and quantitative descriptions. The results showed that the use of the } \\
\text { drill method and the Jarimatika method in arithmetic multiplication } \\
\text { operations material could improve student learning outcomes which } \\
\text { was marked by an increase in mastery, namely the first cycle (64\%) } \\
\text { with an average value of } 68.82 \text {, while in the second cycle (88\%) with } \\
\text { an average value of } 87.64 \text { and declared classically successful } 88 \% \text {. } \\
\text { ABSTRAK Penelitian ini bertujuan untuk meningkatkan hasil belajar } \\
\text { materi operasi perkalian matematika siswa dengan menggunakan } \\
\text { metode drill dan metode Jarimatika. Penelitian tindakan kelas ini } \\
\text { dilaksanakan dalam } 2 \text { siklus dengan empat tahapan, yaitu: } \\
\text { perencanaan, pelaksanaan, observasi, refleksi. Subjek penelitian ini } \\
\text { adalah siswa kelas III MI Miftahut Tholibin Mejobo Kudus sebanyak } \\
17 \text { siswa. Penelitian ini menggunakan teknik analisis deskriptif } \\
\text { kualitatif dan deskripsi kuantitatif. Hasil penelitian menunjukkan } \\
\text { bahwa penggunaan metode drill dan metode jarimatika dalam materi } \\
\text { operasi hitung perkalian matematika dapat meningkatkan hasil belajar } \\
\text { siswa yang ditandai dengan peningkatan ketuntasan yaitu siklus I } \\
\text { (64\%) dengan nilai rata-rata } 68,82 \text {, sedangkan pada siklus II (88\%) } \\
\text { dengan nilai rata-rata } 87,64 \text { dan dinyatakan berhasil secara klasikal } \\
88 \% \text {. }\end{array}$ \\
\hline
\end{tabular}

\section{A. PENDAhUluan}

Berhitung merupakan bagian penting dari matematika yang tidak dapat dipisahkan dari kehidupan sehari-hari, mulai dari usia Sekolah Dasar hingga perguruan tinggi . Ada banyak masalah dalam kehidupan sehai-hari yang membutuhkan berhitung. Oleh karena itu, pembelajaran matematika merupakan kebutuhan yang sangat penting. Hal ini dikarenakan pembelajaran matematika melatih siswa untuk berpikir kritis, sistematis, logis dan kreatif. Salah satu keterampilan matematika yang harus dikuasai siswa sekolah dasar atau madrasah ibtida'iyyah adalah perkalian dasar. Banyak guru sekolah dasar atau madrasah ibtida'iyyah yang mengharuskan siswa untuk menghafalnya. siswa yang belum 
menguasai perkalian dasar di kelas bawah akan menjadi kendala pada pelajaran selanjutnya, karena kurikulum matematika selalu runtut.

Siswa kelas III MI NU Miftahut Tholibin Mejobo Kudus rata-rata belum memahami perkalian dasar. Hal ini dikarenakan mereka kurang mampu dengan metode menghafal. Dari hasil evaluasi ulangan harian semester pertama tahun ajaran 2014/2015 dan hasil wawancara dengan guru matematika, hanya $41,2 \%$ siswa yang hasil belajarnya di atas KKM (Kriteria Ketuntasan Minimal) yang ditetapkan 65. Uraian masalah menunjukkan perlunya guru melakukan pembenahan metode pembelajaran guna meningkatkan hasil belajar siswa. Salah satu inovasi metode pembelajaran yang coba kami tawarkan adalah pertukaran pola pembelajaran lama dengan pola pembelajaran baru yang nilainya lebih efektif dan bermakna bagi siswa, dengan menerapkan metode pembelajaran menggunakan metode Jarimatika dan metode Drill.

Metode drill atau latihan adalah cara mengajar dengan memberikan latihan tentang apa yang telah dipelajari siswa untuk memperoleh keterampilan tertentu.(Anitah 2009) Dengan metode drill, siswa langsung dihadapkan pada gambaran konkrit dari konsepkonsep abstrak dalam matematika (Santi and Prihatnani 2018). Siswa terbiasa memecahkan masalah matematika, berulang-ulang agar siswa di kelas matematika mengerti dan memiliki keterampilan. Metode drill adalah suatu cara mengajar dimana siswa melakukan kegiatan latihan agar siswa memiliki ketangkasan atau keterampilan yang lebih tinggi daripada yang dipelajarinya.(Ahmad 1986). Metode drill sebagai metode pengajaran adalah metode mengajar dengan mengulangi beberapa kali apa yang telah diajarkan guru sehingga lebih banyak pengetahuan dan keterampilan yang diperoleh.(Heppy et al. 2009) Hal ini sejalan dengan Teori Behavioristik, yang menggunakan pengulangan dan pengajaran sehingga karakter yang dibutuhkan menjadi pembiasaan. Drill dapat dilaksanakan secara perorangan, kelompok, atau klasikal.

Jarimatika adalah cara mengajarkan anak berhitung dengan menggunakan jarijarinya sebagai alat bantu berhitung(Nasution and Surya 2016). Jarimatika merupakan metode yang dianggap mudah untuk perkalian dasar karena siswa hanya membutuhkan keterampilan bermain dengan jari tanpa menghafal.(Maijuati, Nurfani, and Putra 2021) Dalam penelitian ini, perkalian yang digunakan adalah perkalian dasar yang hasil kalinya kurang dari 100. Perkalian jarimatika dimulai dari angka 6 sampai 10, perkalian angka 1, 2, 3, 4 dan 5 harus bisa dihafal. Meskipun hanya menggunakan tangan, metode ini memungkinkan untuk melakukan berbagai operasi jarimatika.(Jaelani and Aisyah 2017) Sebagai gambaran, nilai jari kelingking adalah 6, jari manis adalah 7, jari tengah adalah 8 , jari telunjuk adalah 9, dan ibu jari adalah 10. Oleh karena itu, penulis memilih Penelitian Tindakan Kelas (PTK) yang berjudul "Penggunaan Metode Jarimatika dan Metode Drill untuk meningkatkan Hasil Belajar Materi Operasi Perkalian pada Siswa Kelas III MI NU Miftahut Tholibin Mejobo Kudus".

\section{B. METODE PENELITIAN}

Jenis penelitian yang digunakan penulis adalah penelitian tindakan di kelas pada mata pelajaran matematika. Penelitian Tindakan Kelas adalah analisis sistematis terhadap upaya sekelompok guru untuk meningkatkan pelaksanaan praktik pendidikan dengan 
melakukan tindakan dalam pembelajaran, berdasarkan refleksi atas hasil tindakan tersebut. Penelitian ini dilaksanakan pada tanggal 23 November 2021 pada semester gasal tahun pelajaran 2021/2022. Dalam pelaksanaannya, penelitian tindakan kelas ini dilakukan dalam 2 siklus dengan menggunakan model Kemmis dan Taggart (Sudarsih, 2021; Nurbaya, 2021). Setiap siklus terdiri dari empat tahapan kegiatan, yaitu perencanaan (planning),pelaksanaan (action), pengamatan (observation), refleksi (reflection). Peneliti mengambil tempat penelitian tindakan kelas di MI NU Miftahut Tholibin Mejobo Kudus.

Subjek penelitian ini adalah siswa kelas III MI NU Miftahut Tholibin Mejobo Kudus yang berjumlah 17 siswa yang terdiri dari 10 laki-laki dan 7 perempuan. Sumber data yang digunakan adalah siswa kelas III MI NU Miftahut Tholibin Mejobo Kudus dan wali kelas sebagai kolaborator dalam penelitian ini. Dalam penelitian tindakan kelas, data yang dikumpulkan dapat berupa kuantitatif atau kualitatif. Data kuantitatif berupa skor dianalisis menggunakan analisis deskriptif komparatif, dengan membandingkan hasil tes kondisi awal, skor tes setelah siklus I dan II khususnya skor dari hasil ulangan harian siswa kelas III MI NU Miftahut Tholibin pada siklus pertama dan kedua.

\section{HASIL DAN PEMBAHASAN}

Berdasarkan observasi awal pada pra siklus diketahui sebelum metode jarimatika dan metode drill pada saat pembelajaran diterapkan hasil belajar siswa pada pra siklus dalam memahami materi cukup sulit, siswa yang aktif hanya sedikit, dengan jumlah yang lebih besar didominasi oleh siswa yang kurang aktif dalam proses belajar mengajar. Tes awal dilakukan guna mengetahui kemampuan dasar siswa pada materi tersebut. Sebelum melaksanakan penelitian tindakan kelas, kolabolator yaitu guru kelas III masih melakukan pembelajaran hitung perkalian dengan metode konvensional dalam bentuk hafalan. Maka hal itu mengakibatkan hasil belajar matematika sebagian siswa belum memenuhi KKM. Data tersebut didapat dari hasil tes awal yang telah dilakukan. Tes awal dilakukan untuk melihat apakah penelitian dapat dilanjutkan atau tidak, dan hasil yang diperoleh dari tes pra siklus menunjukkan bahwa dari 17 siswa, hanya 5 siswa yang memenuhi nilai ketuntasan (skor 65-100). dan masih terdapat 12 siswa yang tidak memenuhi nilai ketuntasan. Bahwa persentase siswa yang lulus hanya $29 \%$ dan masih tersisa $71 \%$ siswa yang mencapai nilai di bawah nilai ketuntasan dengan nilai rata-rata 51,7. Maka dari itu, perlu adanya peneltitian tindakan kelas guna meningkatkan hasil belajar peserta didik dalam pembelajaran matematika khususnya materi perkalian dasar dengan penerapan metode jarimatika dan driil.

\section{Siklus I}

Siklus I ini dilaksanakan pada tanggal 23 November 2021. Pelaksanaan pembelajaran menggunakan metode jarimatika dan metode drill pada siklus I dilaksanakan melalui beberapa tahapan yaitu, perencanaan (planning), pelaksanaan (acting), pengamatan (observation), refleksi (reflection). Pada tahap perencanaan peneliti mengidentifikasi permasalahan dalam pembelajaran yang terdiri dari metode menggajar yang digunakan guru sebelumnya dan hasil belajar siswa yang rendah, menyiapkan RPP dengan penerapan metode jarimatika dan driil. Peneliti juga membuat lembar pengamatan 
untuk guru dalam proses belajar mengajar di kelas, lembar hasil belajar siswa, lembar wawancara dan lembar soal untuk mengevaluasi siswa setelah penerapan metode jarimatika dan driil.

Pada tahap pelaksanaan kolaboator dan peneliti bekerjasama dalam mengimplementasikan RPP yang telah dirancang. Kolaborator mendemonstrasikan ketrampilan berhitung perkalian dengan jarimatika secara bertahap dan berulang-ulang serta memberikan bimbingan untuk menyelesaikan latihan. Kemudian, pada akhir siklus 1 diberikan tes untuk mengetahui peningkatakan hasil belajar setelah diterapkannya metode jarimatika dan driil. Tahap pengamatan, peneliti mengamati arah proses belajar mengajar. Pengamatan dilakukan bersamaan dengan pelaksanaan penelitian tindakan kelas. Aspekaspek yang diamati, diantaranya kemampuan guru membuka pelajaran, kemampuan menyampaikan materi ajar, kemampuan guru menjawab pertanyaan siswa, kemampuan guru menerapkan metode jarimatika, kemampuan guru menerapkan metode driil, kemampuan guru membimbing siswa saat mereka mengerjakan latihan, kemampuan guru mengelola kelas, kemampuan guru menyalurkan perhatian kepada siswa selama pembelajaran dan peran guru dalam memberi motivasi kepada siswa.

Tahapan terakhir, yakni refleksi. Peneliti mengolah hasil pengamatan dan hasil tes pada siklus 1 dengan mendiskusikan hasil pengamatan dan penilaian bersama kolabolator selama proses pembelajaran pada siklus I ditinjau dari tingkat keberhasilannya. Seorang siswa dipandang tuntas belajar jika hasil tesnya di atas KKM. Pada siklus I pembelajaran dengan drill dan Jarimatika menunjukkan adanya peningkatan hasil belajar siswa. Hasil analisis data skor siswa dalam kaitannya dengan materi tes siklus I menunjukkan bahwa persentase hasil tes siswa yang tuntas belajar meningkat sebesar 35\% dibandingkan pra siklus. Hasil tes siklus I siswa pada mata pelajaran matematika kelas III masih cukup memadai, namun masih perlu perbaikan yaitu mencapai rata-rata 68,82, sedangkan Kriteria Ketuntasan Minimal (KKM) yang harus dipenuhi siswa adalah 65. Dari 17 siswa tersebut, Hanya 11 siswa atau $64 \%$ yang berhasil mendapatkan nilai di atas 65 . Artinya pada siklus I siswa belum tuntas, karena siswa yang mendapatkan nilai 70 hanya $64 \%$ kurang dari yang dipersyaratkan.

\section{Siklus II}

Siklus II ini dilaksanakan pada tanggal 23 November 2021. Hasil refleksi siklus I digunakan dalam perbaikan dan pengembangan tindakan pada siklus II. Pelaksanaan tindakan siklus II pada dasarnya adalah untuk membuktikan apakah terjadi perubahan dan peningkatan hasil belajar setelah siswa memperoleh tindakan dalam siklus I. Peneliti tidak perlu melakukan pada siklus selanjutnya jika hasil analisis data menunjukan peningkatan yang signifikan sesuai dengan indikator keberhasilan peneliti yang telah ditetapkan.

Pelaksanaan pembelajaran menggunakan metode jarimatika dan metode drill pada siklus II dilaksanakan sesuai dengan siklus I dengan hasil refleksi yang cukup memuaskan. Refleksi pada siklus II ini dilakukan untuk melakukan penyempurnaan tentang pelaksanaan pembelajaran dengan menggunakan metode jarimatika dan metode drill yang diharapkan dapat meningkatkan hasil belajar siswa dalam proses pembelajaran. Peneliti mengolah hasil pengamatan dan hasil tes pada siklus II. Peneliti mendiskusikan hasil pengamatan dan penilaian dengan kolabolator selama proses pembelajaran pada siklus II 
ditinjau dari tingkat keberhasilannya. Seorang siswa dipandang tuntas belajar jika hasil tesnya di atas KKM.

Hasil tes siklus II, siswa pada mata pelajaran matematika kelas III tergolong baik, dengan rata-rata 87,64. Sedangkan kriteria ketuntasan minimal (KKM) yang harus dipenuhi siswa adalah 70, dari 17 siswa yang lulus ujian matematika sebanyak 15 siswa atau $88 \%$ yang berhasil mendapat nilai lebih dari 70 . Hasil ini menunjukkan bahwa di kelas III siswa sudah lulus, karena siswa yang mendapat nilai 70 hanya $88 \%$ lebih baik dari ketuntasan yang dipersyaratkan, yakni $80 \%$. Hasil observasi aktivitas siswa dikategorikan baik artinya peneliti sudah mulai meminimalisir kekurangan sampai saat ini. Aktivitas siswa dalam memecahkan masalah secara kelompok, diskusi dengan teman sekelas dapat berupa berbagi jawaban yang berbeda, mempresentasikan hasil diskusi dengan teman sekelas di depan kelas yang mengalami peningkatan dibandingkan siklus sebelumnya. Oleh karena itu peneliti dan pengamat menganggapnya cukup baik.

Hasil penelitian tindakan kelas menunjukkan bahwa observasi peneliti bersama kolaborator terhadap aktivitas guru dan siswa melalui penerapan metode jarimatika dan metode drill dapat dilihat pada tabel berikut.

Tabel 1. Ketuntasan hasil belajar siswa pada pra siklus, siklus 1 dan siklus 2

\begin{tabular}{cccc}
\hline & \multicolumn{2}{c}{ Peningkatan hasil belajar } & \multirow{2}{*}{ Keterangan } \\
\cline { 1 - 3 } Pra Siklus & Siklus 1 & Siklus 2 & Jumlah Siswa Lulus \\
\hline 5 & 11 & 15 & Persentase siswa yang lulus \\
\hline $29 \%$ & $64 \%$ & $88 \%$ & Ketuntasan secara klasikal
\end{tabular}

Berdasarkan kegiatan pembelajaran yang telah berlangsung dengan menggunakan metode drill, tujuan pembelajarannya adalah kemampuan mengatasi kesulitan belajar siswa yang lebih aktif, kreatif dalam proses belajar mengajar (Thoiyyibah 2020). Kegiatan siklus II menunjukkan tidak ada kendala dalam penyusunan Rencana Aksi (RPP).(Heppy et al. 2009) Hal ini sejalan dengan pandangan (Wulandari, 2008) yang menyatakan bahwa metode drill and Practice membimbing siswa melalui latihan-latihan untuk meningkatkan ketangkasan/kecekatan dan kefasihan/kefasihan dalam keterampilan. Jarimatika adalah salah satu cara untuk melakukan operasi aritmatika(Himmah, Makmur, and Nuraini 2021). Jika kita melakukan latihan numerik dengan siswa kita berulang kali, kita tidak perlu khawatir, siswa pasti akan menguasai keterampilan ini dengan baik. Jarimatika dapat membantu siswa mengenal proses berhitung dan tata cara berhitung dengan cara yang sederhana dan menyenangkan (Wulandari, 2008). Sedangkan menurut (Prasetyono, 2008) menyatakan bahwa metode jarimatika adalah metode menghitung matematika dengan menggunakan alat bantu jari.

Metode jarimatika tidak menghilangkan konsep operasi matematika, tetapi proses perhitungannya dapat disederhanakan dan dipercepat. (Sitio 2017) Metode ini mungkin primitif, tetapi mudah diterima dan dipahami siswa, dan juga cukup menarik, praktis, sederhana dan ekonomis karena hanya menggunakan sepuluh jari kita. Oleh karena itu, metode ini dapat diberikan kepada siswa yang kekuatan genggamannya lemah atau yang kecerdasannya lemah. Dengan terbiasanya siswa melakukan latihan berulang/drilling 
maka hasil belajar perkalian dasar pada siswa kelas III MI NU Miftahut Tholibin mengalami peningkatan. Hal ini menunjukkan bahwa penerapan metode Jarimatika dan metode drill efektif.

\section{PENUTUP}

\section{Simpulan}

Penerapan metode Jarimatika dan metode drill dalam pembelajaran matematika materi perkalian dasar di kelas III MI NU Miftahut Tholibin Mejobo Kudus dilakukan dengan menyiapkan skenario pembelajaran dan alat peraga berupa tes hasil belajar dan kegiatan pembelajaran. Selain itu proses pembelajaran dilakukan dengan demonstrasi berulang-ulang keterampilan atau latihan berhitung, kemudian siswa dinilai melalui tes, pada fase tindakan ini memonitor aktivitas belajar siswa setelah hasil belajar dan pembelajaran aktif siswa pada perkalian dasar. pembelajaran, kemudian peneliti dan kolaborator memikirkan kegiatan dan melakukan perbaikan untuk dilakukan pada siklus berikutnya.

\section{Saran}

Penerapan metode jarimatika dan $d r i i l$ sangat efektif diterapkan dalam pembelajaran matematika. Dengan demikian peneliti memberikan saran terhadap :

1. Bagi Siswa

Materi perkalian membutuhkan pemahaman siswa dalam menguasaan penjumlahan. Oleh karena itu, hendaknya siswa telah menguasai materi penjumlahan pada kelas sebelumnya, agar pembelajaran pada materi perkalian tidak terganggu.

2. Bagi Guru

a. Berdasarkan hasil penelitian, metode jarimatika dan driil mampu meningkatkan hasil belajar matematika, sehingga metode ini dapat menjadi salah satu alternatif pembelajaran matematika yang dapat diterapkan oleh guru.

b. Pembelajaran dengan menggunakan metode jarimatika dan driil membutuhkan penjelasan yang cukup jelas agar dapat tersampaikan dengan baik kepada siswa. Untuk itu, guru dapat mempersiapkan dan mengkondisikan siswa sebaik mungkin agar pembelajaran dapat diselesaikan dengan baik dan tujuan pembelajaran dapat tercapai.

3. Bagi Madrasah

Berdasarkan hasil penelitian, bahwa salah satu faktor yang dapat menunjang pembelajaran adalah dengan perencanaan yang baik termasuk didalamnya adalah metode pembelajaran yang diterapkan oleh guru. Oleh karena itu, diharapkan pihak madrasah untuk dapat berkomunikasi dan mengevaluasi kegiatan pembelajaran yang dilaksanakan sebagai upaya pengembangan pembelajaran berikutnya. 


\section{DAFTAR PUSTAKA}

Ahmad, A. (1986). Metode Khusus Pendidikan Agama. Bandung: Cv Amrico.

Anitah, Sri. (2009). Teknologi Pembelajaran. Surakarta: Yuma Pustaka.

Bahri, Djamarah. (2002). Psikologi Belajar. Jakarta: Rineka Cipta.

Heppy, Dessy, Pratiwi Soleh, Zaenal Abidin, and Jati Ariati. (2009). "Pengaruh Metode Jarimatika Terhadap Prestasi Belajar Matematika Siswa Tunanetra Sekolah Dasar SLB Negeri 1 Pemalang.” Jurbnal Psikologi Undip Vol. 10, N: 115-25.

Himmah, Khusnul, Jamal Makmur, and Latifah Nuraini. (2021). "Efektivitas Metode Jarimatika Dalam Meningkatkan Kemampuan Berhitung Perkalian Siswa." Dawuh Guru Jurnal Pendidikan MI/Sd 1 (1): 57-68.

Jaelani, Aceng, and Siti Aisyah. (2017). "Pengaruh Metode Drill Terhadap Hasil Belajar Matematika Materi Perkalian Pada Siswa Kelas III MIN Kota Cirebon." Al Ibtida Jurnal Pendidikan Guru MI 4 (1): 87-96.

Maijuati, Nurfani, and Riandi Syah Putra. (2021). "Penggunaan Metode Jarimatika Perkalian Untuk Meningkatkan Kemampuan Berhitung Warga Masyarakat Penyandang Buta Aksara Di Pkbm Bangkit Aceh Kabupaten Aceh Besar." Jurnal AKRAB XII (I): 10-17.

Nasution, Tetty Khairani, and Edy Surya. (2016). "Penerapan Teknik Jarimatika Dalam Upaya Meningkatkan Kemampuan Operasi Hitung Perkalian Bilangan." Union Jurnal Pendidikan Matematika 4 (2): 239-52.

Nurbaya, S. (2021). Peningkatan Kemampuan Berpikir Kritis dan Penyelesaian Masalah Melalui Model Problem Based Learning (PBL) pada Pembelajaran Tematik Kelas VI SDN 19 Cakranegara. Pendagogia: Jurnal Pendidikan Dasar, 1(2), 106-113.

Peni Wulandari, Septi. (2008). Jarimatika Perkalian Dan Pembagian. Jakarta: Kawan Pustaka.

Prasetyono, Dwi Sunar; Dkk. (2008). Pintar Jarimatika. Yogyakarta: Diva Press.

Santi, Aprilia, and Erlina Prihatnani. (2018). "Perbandingan Metode Drill Dan Metode Discovery Learning Ditinjau Dari Hasil Belajar Matematika." Prisma, Prosiding Smeinar Nasional Matematika 1: 943-53.

Sudarsih, A. (2021). Penerapan Strategi Discovery Learning dengan Metode Diskusi untuk Meningkatkan Aktivitas Bertanya dan Hasil Belajar IPA Peserta Didik Kelas VI B SDN 19 Cakranegara Tahun Pelajaran 2019/2020. Pendagogia: Jurnal Pendidikan Dasar, 1(2), $114-120$.

Sitio, Tiarmina. (2017). "Penerapan Metode Jarimatika Untuk Meningkatkan Hasil Belajar Matematika Siswa Kelas I SDN 003 Pagaran Tapah Darussalam Kabupaten Rokan Hulu." Jurnal Primary 6 (September): 146-56.

Thoiyyibah, Dzurriyatin. (2020). "Metode Jaritmatika Untuk Melatih Kemampuan Berhitung Penjumlahan Dan Pengurangan Peserta Didik Kelas 2 SD.” Jurnal Pendidikan Dasar: Jurnal Tunas Nusantara 2: 231-41. 